\title{
Marker-assisted introgression improves Striga resistance in an Eritrean Farmer-Preferred Sorghum Variety
}

\author{
Tadesse Yohannes ${ }^{\mathrm{a}, \mathrm{f}}$, Tesfamichael Abraha ${ }^{\mathrm{b}}$, Dan Kiambi ${ }^{\mathrm{c}}$, Rolf Folkertsma ${ }^{\mathrm{d}}$, \\ C. Tom Hash ${ }^{\mathrm{e}}$, Kahiu Ngugi ${ }^{\mathrm{f}}$, Eunice Mutitu ${ }^{\mathrm{f}}$, Negusse Abraha ${ }^{\mathrm{a}}$, Mussie Weldetsion ${ }^{\mathrm{a}}$, \\ Charles Mugoya $^{\mathrm{g}}$, Clet W. Masiga ${ }^{\mathrm{g}}$, Santie de Villiers ${ }^{\mathrm{h}, \mathrm{i}, *}$
}

\author{
National Agricultural Research Institute, PO Box 4627, Asmara, Eritrea \\ ${ }^{\mathrm{b}}$ Hamelmalo Agricultural College, PO Box 397, Keren, Eritrea \\ ${ }^{c}$ African Biodiversity Conservation and Innovations Centre, PO Box 100882-00101, Nairobi, Kenya \\ d Monsanto Holland B.V., Bergschenhoek, The Netherlands \\ e ICRISAT-Sahelian Center, BP 12404 Niamey, Niger \\ f University of Nairobi, PO Box 39063-00623, Nairobi, Kenya \\ ${ }^{g}$ Association for Strengthening Agricultural Research in Eastern and Central Africa, PO Box 765, Entebbe, Uganda \\ ${ }^{\mathrm{h}}$ International Crops Research Institute for the Semi-Arid Tropics (ICRISAT), PO Box 39063-00623, Nairobi, Kenya

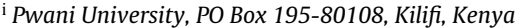

\section{A R T I C L E I N F O}

\section{Article history:}

Received 7 October 2014

Received in revised form

13 December 2014

Accepted 13 December 2014

\section{Keywords:}

Marker-assisted selection

SSR

Sorghum

Striga

Eritrea

\begin{abstract}
A B S T R A C T
The parasitic weed Striga hermonthica hampers the production of sorghum, the most important cereal crop in Eritrea. This weed has a complex mode of infestation that adapts to many hosts and environments, complicating conventional breeding for resistance, which is the only form of crop improvement available to Eritrean breeders, but has failed. This study aimed at improving resistance against this parasite by transferring 5 Striga resistant Quantitative Trait Loci (QTLs) from resistance donor N13 to Striga susceptible Farmer-Preferred Sorghum Variety (FPSV) Hugurtay from Eritrea. The method involved backcrossing using marker-assisted selection (MAS) and evaluation of the best introgressed lines for Striga resistance in artificially infested fields. Foreground selection was performed with up to 11 polymorphic simple sequence repeat (SSR) markers linked to Striga resistance QTLs, while background selection was conducted in the $\mathrm{BC}_{3} \mathrm{~F}_{2}$ generation with 27 polymorphic unlinked SSR markers to identify the best recovery of the recurrent parent (RP) genetic background. Out of $84 \mathrm{BC}_{3} \mathrm{~F}_{3}$ lines, L2P3-B, L1P5-A and L2P5P35 performed best with respect to both grain yield and reduced Striga infestation. These lines were more resistant to Striga than Hugurtay, but less resistant than N13. The three lines yielded twice as much as N13, with Area Under Striga Number Progression Curve (AUSNPC) values on average 18\% higher than that of N13 and 38\% lower than that of Hugurtay. This suggests that the introgressed QTLs conferred significant Striga resistance and yield advantage to these $\mathrm{BC}_{3} \mathrm{~F}_{3}$ backcross progenies under Striga pressure. These lines have good potential for future release and demonstrate that when MAS is available to conventional breeders, even in countries with no genotyping facilities, it is a useful tool for enhancement, expediency and precision in crop improvement.
\end{abstract}

(C) 2015 Published by Elsevier B.V.

\section{Introduction}

Sorghum [Sorghum bicolor (L.) Moench] is the world's fifth most important cereal crop after wheat, maize, rice, and barley (FAOSTAT, 2011). Sorghum forms an important dietary component of many people globally, especially in the arid and semi-arid parts

\footnotetext{
* Corresponding author at: Pwani University, PO Box 195-80108, Kilifi, Kenya. Tel.: +254 729369758 .

E-mail address: s.devilliers@pu.ac.ke (S. de Villiers).
}

of Africa and Asia. In Eritrea sorghum grain is a major staple food prepared as 'enjera' (leavened bread) or as thick porridge, and the stover is used for animal feed. Sorghum is widely grown in the lowland and mid-highland regions of Eritrea where rainfall is too low for cultivation of most other cereals (Tesfamichael et al., 2013). Nationally, sorghum is grown on more than 200,000 ha annually and accounts for $50 \%$ of total food grain production, but with average productivity of less than $1 \mathrm{t} \mathrm{ha}^{-1}$ (Ministry of Agriculture, 2010).

The major biotic constraint to sorghum production in Eritrea is Striga hermonthica, which affects the majority of farmers in the western part of the country in areas such as Goluj and Shambiko 


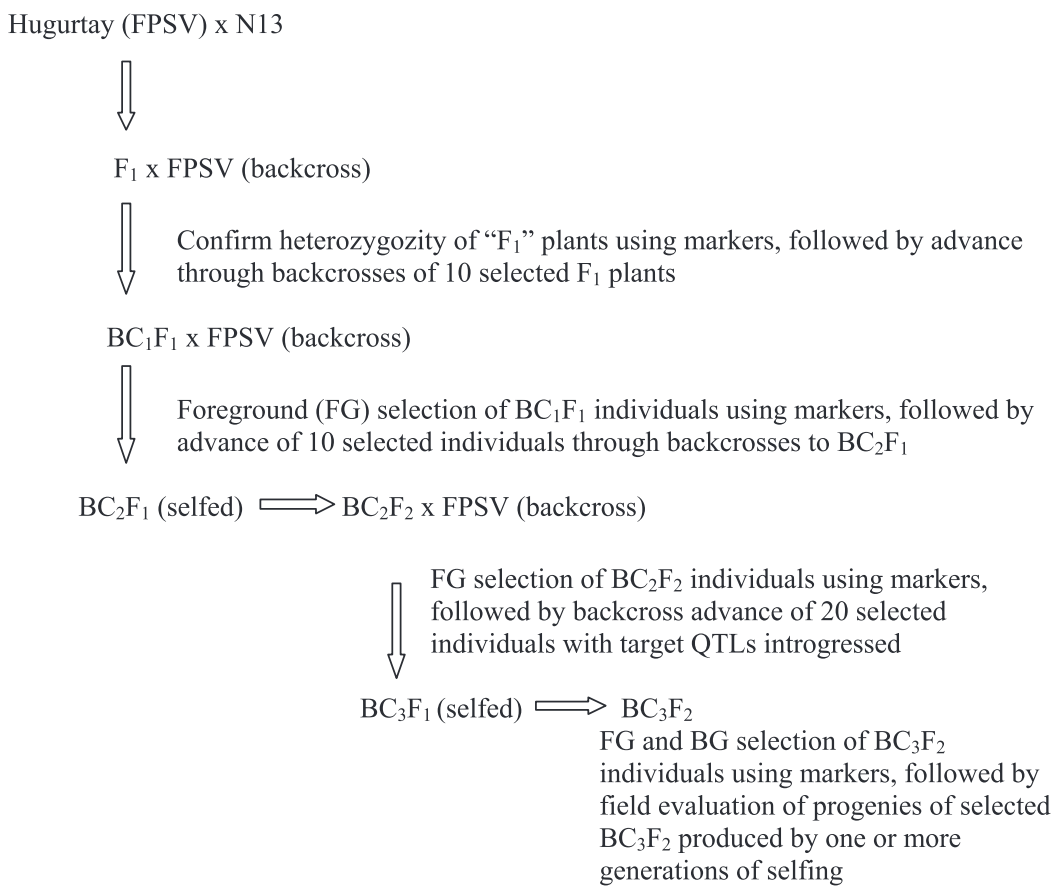

Fig. 1. Scheme of crossing, backcrossing, selfing and marker-assisted selection to generate Striga resistant introgression lines in Farmer Preferred Sorghum Variety, Hugurtay, background.

sub-regions. It is prevalent where continuous mono-cropping is practiced and where wild sorghum is prevalent, and its infestation is aggravated by frequent droughts. Yield losses due to Striga in Eritrea are estimated at $20-50 \%$ of annual sorghum production depending on the rainfall situation.

Efforts to control Striga by conventional breeding for resistant varieties are time consuming and have met with few successes unless aided by laboratory screening methods in advanced laboratories (Ejeta and Gressel, 2007). MAS is a useful tool in plant breeding programs for more efficient selection (Lammerts van Bueren et al., 2010) and involves the identification of genotypes carrying desirable alleles, using linked genetic markers. Breeders practice MAS when an important trait that is difficult to assess phenotypically, is tightly linked to a Mendelian trait or molecular markers that can be easily scored (Lammerts van Bueren et al., 2010). The use of molecular markers to breed for Striga resistance in sorghum has recently been shown to be possible (Ejeta and Gressel, 2007; Gammar and Mohamed, 2013; Mohamed et al., 2014). Haussmann et al. (2004) identified molecular markers linked to Striga resistance QTLs having mechanisms over and above the "low germination stimulant" trait. These authors reported 5 genomic regions (QTLs) associated with stable Striga resistance from resistant variety N13 that were identified based on screening across a series of field trials in Mali and Kenya. Three QTLs were identified, one each on linkage groups SBI-01, SBI-02 and SBI-06 and 2 QTLs on linkage group SBI-05 using the revised linkage group designations proposed by Kim et al. (2004).

Although MAS is an accepted and often routine technology in modern breeding programs with access to state-of-the-art genotyping facilities, breeders in many developing countries including Eritrea improve crops using only phenotypic selection for a trait like Striga resistance, this entails challenging every generation in infested fields to identify superior individuals. Seeds of these individuals then must be increased for replicated field trials to confirm that the phenotype is true. Conventional backcross breeding takes at least 6 or more generations including the initial crossing generation (Hospital and Charcosset, 1997), as well as two generations of selfing following production of the $\mathrm{BC}_{6} \mathrm{~F}_{1}$ generation (to produce
$\mathrm{BC}_{6} \mathrm{~F}_{3}$ seed on $\mathrm{BC}_{6} \mathrm{~F}_{2}$ individuals), and at least one generation of progeny-based testing to identify the desired introgression(s) homozygotes. An important advantage of MAS is that it can reduce the number of backcross generations needed to arrive at the target variety with the introgressed trait(s) (Hospital and Charcosset, 1997; Frisch et al., 1999). For sorghum, with adequate numbers of linked markers, the desired introgression can be achieved within 2-4 backcross generations.

This study aimed to provide Eritrean breeders access to MAS technology in a collaborative experimental design that made use of genotyping facilities and expertise at ICRISAT-Nairobi. All of the field-based work of crossing and advancing generations was done in Eritrea and genotyping was done at ICRISAT-Nairobi with the ultimate objective to transfer resistance alleles at the 5 identified Striga resistance QTLs from N13 to Hugurtay, a popular but Strigasusceptible Farmer-Preferred Sorghum Variety (FPSV) in Eritrea, using marker-assisted backcrossing (MABC) followed by evaluation of the introgressed lines for improved Striga resistance under artificially infested conditions in the field.

\section{Materials and methods}

Hugurtay (FPSV) was crossed with N13 (resistance donor) and three backcross generations were generated with Hugurtay as RP (Fig. 1). All the breeding activities, selection and collection of tissue samples for DNA extraction were done in Eritrea, and DNA sample preparation and genotyping, and final field evaluation under enhanced Striga pressure, were done in Kenya.

\subsection{SSR genotyping}

Tissue samples were collected in Eritrea from individual plants and shipped to ICRISAT-Nairobi for genotyping. DNA extraction was performed following Mace et al. (2003) with exclusion of the phenol extraction step. The DNA quantity and quality was checked using a Nanodrop ${ }^{\circledR}$ spectrophotometer (Thermo Scientific) and electrophoresis on agarose gels $(0.8 \%, \mathrm{w} / \mathrm{v})$ stained with GelRed (Biotium, USA). 
Table 1

Polymorphic SSR markers and their allele sizes at Striga resistance QTL position that were used in foreground screening for QTL introgression in N13 $\times$ Hugurtay progenies.

\begin{tabular}{lllll}
\hline $\begin{array}{l}\text { Linkage group } \\
\text { (QTL name) }\end{array}$ & Marker name & $\begin{array}{l}\text { Physical map } \\
\text { position (Mbp) }\end{array}$ & \multicolumn{2}{l}{ Allele size } \\
\cline { 4 - 5 } & & & N13 & Hugurtay \\
\hline SBI-01 (QTL01) & Xtxp208 & - & 260 & 249 \\
& Xtxp302 & 9.048 & 237 & 229 \\
SBI-02 (QTL02) & Xtxp050 & 5.080 & 317 & 323 \\
& Xtxp201 & - & 202 & Absent \\
& Xtxp304 & 5.703 & 324 & 318 \\
SBI-06 (QTL06) & Xtxp057 & 57.419 & 260 & 269 \\
& Xtxp145 & 49.285 & 260 & 220 \\
SBI-05 & Xtxp303 & 5.729 & 169 & 180 \\
(QTL05 $) ~$ & Xtxp065 & 1.907 & 150 & 145 \\
SBI-05 & Xtxp225 & - & 184 & 194 \\
(QTL05 $)$ & Xtxp15 & 42.050 & 236 & 238 \\
\hline
\end{tabular}

Key: $\mathrm{SBI}=$ Sorghum bicolor linkage group.

SSR genotyping was done in the $\mathrm{F}_{1}, \mathrm{BC}_{1} \mathrm{~F}_{1}, \mathrm{BC}_{2} \mathrm{~F}_{2}$ and $\mathrm{BC}_{3} \mathrm{~F}_{2}$ generations using 5 to 11 markers linked to the Striga resistance QTLs (Haussmann et al., 2004) that were polymorphic between Hugurtay and $\mathrm{N} 13$ (Table 1) for foreground genotyping, and using 27 polymorphic markers that were distributed across the remainder of the sorghum genome (Table 2) for background genotyping in the $\mathrm{BC}_{3} \mathrm{~F}_{2}$ generation. Forward primers had an additional $19 \mathrm{bp}$ phage $\mathrm{M} 13$ sequence at the $5^{\prime}$ end (CACGACGTTGTAAAACGAC) to allow the

Table 2

Polymorphic SSR markers and their allele sizes that were distributed across all ten sorghum linkage groups and were used in background screening to assess recovery of the Hugurtay genotype background in $\mathrm{BC}_{3} \mathrm{~F}_{2}$ individuals homozygous for Striga resistance QTL alleles from donor parent N13.

\begin{tabular}{|c|c|c|c|c|}
\hline \multirow[t]{2}{*}{$\begin{array}{l}\text { Linkage } \\
\text { group }\end{array}$} & \multirow[t]{2}{*}{$\begin{array}{l}\text { Marker } \\
\text { name }\end{array}$} & \multirow[t]{2}{*}{$\begin{array}{l}\text { Physical map } \\
\text { position (Mbp) }\end{array}$} & \multicolumn{2}{|l|}{$\begin{array}{l}\text { Allele } \\
\text { size }\end{array}$} \\
\hline & & & N13 & Hugurtay \\
\hline \multirow[t]{3}{*}{ SBI-01 } & Xtxp032 & - & 157 & 153 \\
\hline & Xcup053 & 72.905 & 205 & 214 \\
\hline & Xtxp357 & 23.806 & 260 & 268 \\
\hline \multirow[t]{2}{*}{ SBI-02 } & Xtxp214 & 60.443 & 242 & 294 \\
\hline & Xtxp298 & 57.081 & 343 & 294 \\
\hline \multirow[t]{4}{*}{ SBI-03 } & Msbcir276 & 55.555 & 246 & 250 \\
\hline & Xisp0307 & - & 361 & 378 \\
\hline & Xtxp183 & - & Absent & 296 \\
\hline & Xtxp285 & 67.824 & 270 & 218 \\
\hline \multirow[t]{2}{*}{ SBI-04 } & Xtxp024 & 58.547 & 173 & 189 \\
\hline & Xisep0228 & 9.994 & 113 & 215 \\
\hline SBI-05 & Msbcir248 & 4.746 & 138 & 148 \\
\hline SBI-06 & Xtxp057 & 57.419 & 260 & 268 \\
\hline \multirow[t]{3}{*}{ SBI-07 } & Msbcir300 & 58.286 & 135 & 130 \\
\hline & Xtxp295 & 61.172 & 177 & 191 \\
\hline & Xtxp040 & 0.861 & 161 & 156 \\
\hline \multirow[t]{2}{*}{ SBI-08 } & Msbcir240 & 4.468 & 125 & 129 \\
\hline & Xtxp250 & 51 & 267 & 270 \\
\hline \multirow[t]{5}{*}{ SBI-09 } & Xcup002 & 8.144 & 221 & 213 \\
\hline & Xgap015 & 6.113 & 129 & 134 \\
\hline & Xtxp010 & 47.917 & 153 & 158 \\
\hline & Xtxp287 & 4.242 & 343 & 373 \\
\hline & Xtxp289 & 0.024 & 342 & 291 \\
\hline \multirow[t]{4}{*}{ SBI-10 } & Xcup016 & 57.842 & 254 & 252 \\
\hline & Msbcir283 & 18.1 & 134 & 160 \\
\hline & Xgap001 & 54.507 & 273 & 271 \\
\hline & Xtxp141 & 58.245 & 155 & 183 \\
\hline
\end{tabular}

Key: $\mathrm{Mbp}=$ Mega basepair. incorporation of fluorescent dyes (FAM, NED, PET or VIC) following the method described by Schuelke (2000). PCR reaction mixtures contained $2 \mathrm{mM} \mathrm{MgCl}, 0.20 \mu \mathrm{M}$ reverse primer, $0.04 \mu \mathrm{M}$ forward primer, $0.16 \mu \mathrm{M}$ labeled M13 forward primer, $0.04 \mathrm{mM}$ of each of the four dNTPs and 0.2 U DNA polymerase (Sibenzyme) and $30 \mathrm{ng}$ template DNA in a $10 \mu \mathrm{l}$ reaction volume. Amplification was done on a GeneAmp PCR systems 9600 thermocycler (Applied Biosystems) using initial denaturation at $94{ }^{\circ} \mathrm{C}$ for $15 \mathrm{~min}$, followed by 35 cycles of denaturation at $94^{\circ} \mathrm{C}$ for $30 \mathrm{~s}$, annealing at $50^{\circ} \mathrm{C}$ for $1 \mathrm{~min}$ and extension at $72{ }^{\circ} \mathrm{C}$ for $2 \mathrm{~min}$. Final extension was at $72{ }^{\circ} \mathrm{C}$ for $20 \mathrm{~min}$.

Fragment analysis was carried out by capillary electrophoresis using an ABI PRISM 3730 (Applied Biosystems), automated sequencer as described by Folkertsma et al. (2005). Up to 4 markers were analyzed simultaneously by combining $1.5-2.5 \mu$ l of each labeled PCR product with formamide and $0.16 \mu \mathrm{l}$ Genescan Liz 500 molecular weight standard (Applied Biosystems). Allele scoring was done using GeneMapper ${ }^{\circledR}$ Software V4.0 as described by Hayden et al. (2008).

\subsection{Evaluation of $B C_{3} F_{2}$-derived progenies for Striga resistance in artificially infested fields}

Following marker-assisted selection, progenies from selfed $\mathrm{BC}_{3} \mathrm{~F}_{2}$ individuals with 1-4 Striga resistance QTLs, were evaluated for improved Striga resistance in the field. During the first season, $84 \mathrm{BC}_{3} \mathrm{~F}_{2}$-derived lines $\left(\mathrm{BC}_{3} \mathrm{~F}_{3}\right.$ generation $)$ were screened using an augmented design at Alupe, Kenya. During the second season, selfed progenies of $30 \mathrm{BC}_{3} \mathrm{~F}_{3}$ lines $\left(\mathrm{BC}_{3} \mathrm{~F}_{4}\right.$ generation) that performed better than Hugurtay in the field during the first season were evaluated at two locations in Kenya (Alupe $00^{\circ} 29^{\prime} \mathrm{N}, 34^{\circ} 08^{\prime} \mathrm{E}$, $1189 \mathrm{~m}$ altitude and Kibos $00^{\circ} 04^{\prime} \mathrm{S}, 34^{\circ} 48^{\prime} \mathrm{E}, 1214 \mathrm{~m}$ altitude) in an alpha-lattice design, replicated three times with parents N13 and Hugurtay included as checks. At sowing, each hill was infested with Striga seeds, prepared by mixing $5 \mathrm{~g}$ of seeds with $5 \mathrm{~kg}$ of washed sand and applying 1 tablespoon of inoculum to each hill (Jamil et al., 2012). At 21 days after sowing, seedlings were thinned to $0.2 \mathrm{~m}$ between plants and one plant per hill. First weeding, excluding Striga, was done by hoe with subsequent weeding done by hand to avoid disturbing emerging and established Striga plants.

In all three experiments, progenies were evaluated for days to $50 \%$ flowering, plant height, grain yield, days to Striga emergence, emerged Striga count, number of Striga plants flowered, number of Striga plants forming seed capsules, and Striga vigor on a scale of 1-9 adopted from Haussmann et al. (2000). Successive Striga counts were used to calculate the Area Under Striga Number Progress Curve (AUSNPC) as described by Haussmann et al. (2000).

\subsection{Field data analysis}

Data on agronomic performance and Striga parameters were subjected to analysis of variance (ANOVA) using Genstat ${ }^{\circledR} 15$ th Edition (http://www.vsni.co.uk). Treatment means were separated using the least significance difference test. Relationships among parameters were tested using Pearson's correlation coefficient. On Striga counts, logarithmic transformations $(\log (X+c)$, where $X$ is the original individual observation and $c=1.0$ ) were applied as described by Rodenburg et al. (2005).

\section{Results}

\subsection{Foreground and background genotyping}

DNA extraction yielded good quality genomic DNA of 5.2-13.7 $\mu$ g per sample. Polymorphism screening between N13 and Hugurtay for both foreground and background markers allowed 
Table 3

Number of individuals genotyped in the F1 and subsequent backcross (BC) generations.

\begin{tabular}{lccc}
\hline Generation & $\begin{array}{l}\text { Individuals } \\
\text { genotyped }\end{array}$ & $\begin{array}{l}\text { Individuals with QTLs } \\
\text { introgressed }\end{array}$ & $\begin{array}{l}\text { Individuals advanced } \\
\text { to next generation }\end{array}$ \\
\hline $\mathrm{F}_{1}$ & 10 & 10 & 4 \\
$\mathrm{BC}_{1} \mathrm{~F}_{1}$ & 23 & 23 & 10 \\
$\mathrm{BC}_{2} \mathrm{~F}_{1}$ & 0 & - & 17 \\
$\mathrm{BC}_{2} \mathrm{~F}_{2}$ & 58 & 42 & 20 \\
$\mathrm{BC}_{3} \mathrm{~F}_{1}$ & 0 & - & 11 \\
$\mathrm{BC}_{3} \mathrm{~F}_{2}$ & 341 & 216 & 84 \\
\hline
\end{tabular}

Key: QTL = quantitative trait locus.

selection of a total of 11 foreground SSRs (Table 1) and 27 background SSR markers (Table 2), which were used to screen one or more generations of the backcross progenies. Foreground SSRs are markers that are linked to the target QTL, which enable identification and selection of plants having the alleles of the donor parent at the target loci. Background SSRs are markers that are spread across the genome and not linked to the target QTL, which help to assess the recovery of the recurrent parent genotype.

For genotyping the $\mathrm{F}_{1}, \mathrm{BC}_{1} \mathrm{~F}_{1}$ and $\mathrm{BC}_{2} \mathrm{~F}_{2}$ generations, only 7 polymorphic foreground SSR markers were identified that allowed indirect selection for 4 Striga resistance QTLs: Xtxp208 and Xtxp302 (linked to QTL01), Xtxp050, Xtxp201 and Xtxp304 (linked to QTL02), Xtxp303 (linked to QTL05 1 ) and Xtxp225 (linked to QTL052). No markers were available to screen for QTL06. The number of individuals genotyped and selected during each generation, excluding the parents, is shown in Table 3.

In $F_{1}, 10$ plants were genotyped with 6 foreground markers to confirm that they were true hybrids of N13 and Hugurtay. In the $\mathrm{BC}_{1} \mathrm{~F}_{1}$ generation 23 plants were screened with the 7 polymorphic foreground markers, of which $12 \mathrm{BC}_{1} \mathrm{~F}_{1} \mathrm{~s}$ showed introgression of 1 QTL, 9 of 2 QTLs and 2 of 3 QTLs (Table 4). Ten representative $\mathrm{BC}_{1} \mathrm{~F}_{1}$ plants with different QTL introgression combinations were selected and advanced to $\mathrm{BC}_{2} \mathrm{~F}_{1}$. Seventeen plants of $\mathrm{BC}_{2} \mathrm{~F}_{1}$ were selfed and subsequently, foreground genotyping in $\mathrm{BC}_{2} \mathrm{~F}_{2}$ was done on 58 individuals with the same 7 markers as used for the $\mathrm{BC}_{1} \mathrm{~F}_{1}$ plants. From these, 42 plants were identified with introgressed QTLs of which 23 plants showed homozygous donor QTL alleles (Table 4) and 20 of these plants were selected for advance to $\mathrm{BC}_{3} \mathrm{~F}_{1}$.

Selfed seeds from $11 \mathrm{BC}_{3} \mathrm{~F}_{1}$ plants were sent to ICRISAT-Kenya where the $\mathrm{BC}_{3} \mathrm{~F}_{2}$ plants were genotyped for QTL introgressions
Table 4

Summary of the various combinations of QTLs introgressed in heterozygous state in $\mathrm{BC}_{1} \mathrm{~F}_{1}$ and in homozygous state in $\mathrm{BC}_{2} \mathrm{~F}_{2}$.

\begin{tabular}{|c|c|c|}
\hline \multirow[t]{2}{*}{ QTL combinations $^{\mathrm{a}}$} & \multicolumn{2}{|c|}{ Backcross generation } \\
\hline & $\mathrm{BC}_{1} \mathrm{~F}_{1}$ & $\mathrm{BC}_{2} \mathrm{~F}_{2}$ \\
\hline \multicolumn{3}{|l|}{ Single introgressions } \\
\hline QTL01 & 0 & 3 \\
\hline QTL02 & 0 & 0 \\
\hline QTLO5 $_{1}$ & 0 & 1 \\
\hline $\mathrm{QTLO5}_{2}$ & 15 & 3 \\
\hline \multicolumn{3}{|l|}{ Double introgressions } \\
\hline QTL01, QTL02 & 0 & 3 \\
\hline QTL01, QTL052 & 0 & 1 \\
\hline $\mathrm{QTLO2}_{2} \mathrm{QTLO5}_{2}$ & 5 & 0 \\
\hline $\mathrm{QTLO5}_{1}, \mathrm{QTLO5}_{2}$ & 1 & 2 \\
\hline \multicolumn{3}{|l|}{ Triple introgressions } \\
\hline QTL01, QTL02, QTL05 1 & 0 & 1 \\
\hline QTL01, QTL02, QTL052 & 0 & 1 \\
\hline QTL01, QTL05 1 , QTL05 2 & 0 & 8 \\
\hline QTL02, QTL05 1 , QTL05 2 & 1 & 0 \\
\hline \multicolumn{3}{|l|}{4 QTLs introgressed } \\
\hline QTL01, QTL02, QTL05 1, QTL05 $_{2}$ & 1 & 0 \\
\hline Total individuals with QTLs & 23 & 23 \\
\hline
\end{tabular}

a QTL combinations that were not identified in any individuals were not included here. QTL06 was not screened for as polymorphic markers linked to this locus were not available at the time.

and recurrent parent genome background recovery. By this point additional polymorphic markers had been identified, of which at least 2 were linked to each of the 5 QTLs, as indicated in Table 1. A total of $341 \mathrm{BC}_{3} \mathrm{~F}_{2}$ individuals were screened using the 11 polymorphic foreground SSR markers. Of these, 216 were found to have from 1 to 4 homozygous introgressed QTLs as shown in Table 5.

\subsection{Field evaluation of $B C_{3} F_{3}$ lines under Striga infestation}

Combined ANOVA for grain yield across the 2 locations in the second season of field screening in Kenya under Strigainfested conditions revealed that genotypes, environments and genotype $\times$ environment $(\mathrm{G} \times \mathrm{E})$ interaction components of variance were significant (Table 6). However, magnitude of the $\mathrm{G} \times \mathrm{E}$ interaction variation was small compared to that for genotype.

Table 5

Summary of QTL introgressions fixed in $\mathrm{BC}_{3} \mathrm{~F}_{2}$ lines.

\begin{tabular}{|c|c|c|c|c|c|}
\hline \multirow[t]{2}{*}{ QTL combination } & \multirow[t]{2}{*}{ No. of $\mathrm{BC}_{3} \mathrm{~F}_{2}$ lines } & \multicolumn{4}{|c|}{$\mathrm{BC}_{3} \mathrm{~F}_{2}$ lines with QTLs introgressed } \\
\hline & & $1 \mathrm{QTL}$ & 2 QTLs & 3 QTLS & 4 QTLS \\
\hline QTL02 & 31 & & & & \\
\hline QTL06 & 13 & & & & \\
\hline QTL05 $_{1}$ & 4 & & & & \\
\hline $\mathrm{QTLO5}_{2}$ & 93 & 141 & & & \\
\hline QTL01, QTL02 & 1 & & & & \\
\hline QTL01, QTL06 & 1 & & & & \\
\hline QTL01, QTL05 $_{2}$ & 3 & & & & \\
\hline QTL02, QTL06 & 25 & & & & \\
\hline $\mathrm{QTLO}_{2}, \mathrm{QTLO}_{2}$ & 13 & & & & \\
\hline QTL06, QTL05 2 & 8 & & & & \\
\hline QTLO5 $_{1}$, QTLO5 $_{2}$ & 5 & & 56 & & \\
\hline QTL01, QTL02, QTL06 & 3 & & & & \\
\hline QTL01, QTL06, QTL05 2 & 4 & & & & \\
\hline QTL01, QTL05 $_{1}$, QTLO5 $_{2}$ & 3 & & & & \\
\hline QTL02, QTL06, QTL05 2 & 5 & & & & \\
\hline QTL02, QTL051, QTL05 2 & 2 & & & 17 & \\
\hline QTL01, QTL02, QTL06, QTL05 2 & 2 & & & & 2 \\
\hline Sub-total & 216 & & & & \\
\hline Individuals with no introgressed QTLs & 125 & & & & \\
\hline Total genotyped $\mathrm{BC}_{3} \mathrm{~F}_{2}$ individuals & 341 & & & & \\
\hline
\end{tabular}


Table 6

Combined analysis of variance for grain yield across locations.

\begin{tabular}{lccclr}
\hline Fixed term & Wald statistic & n.d.f. & $F$ statistic & d.d.f. & \multicolumn{1}{c}{$F$ pr } \\
\hline Env & 11.19 & 1 & 11.19 & 26.1 & 0.003 \\
Gen & $10,515.9$ & 31 & 334.57 & 90.9 & $<0.001$ \\
Env $\times$ Gen & 129.36 & 31 & 4.12 & 91 & $<0.001$ \\
\hline
\end{tabular}

Key: Env=Environment, Gen=Genotype, n.d.f. = numerator degrees of freedom, d.d.f. $=$ denominator degrees of freedom, $\mathrm{F} \mathrm{pr}=\mathrm{F}$ probability.

Genotypes differed significantly $(P<0.05)$ for all the observed traits (Table 7). The $G \times$ E interaction was also significant for parameters like plant height, grain yield, days to Striga emergence, AUSNPC, number of Striga plants that flowered and Striga vigor. $\mathrm{G} \times \mathrm{E}$ interaction was not significant for days to $50 \%$ flowering and number of Striga plants forming capsules/seeds.

Parameters used to evaluate improved backcross genotypes for Striga resistance were grain yield under Striga pressure, followed by comparisons with resistant parent $\mathrm{N} 13$ in both locations for low AUSNPC, days to Striga emergence and number of Striga seed capsules formed, as presented in Table 7, following the recommendations of Haussmann et al. (2000). Taller plants and better grain yield as well as low AUSNPC, days to Striga emergence, days to Striga flowering and number of capsules formed was observed for genotypes 23 (L2P3-B), 12 (L2P5P35), 22 (L1P5-A), 24 (L2P6-A) and 25 (L2P7-A). All of these genotypes had either 3 or 4 QTLs fixed
Table 8

Pearson's correlation coefficients for various Striga resistance parameters measured at Alupe and Kibos during September 2012-February 2013.

\begin{tabular}{lrrr}
\hline Correlated traits & \multicolumn{1}{l}{ Alupe } & \multicolumn{1}{l}{ Kibos } & Combined \\
\hline Days to Striga emergence vs AUSNPC & $-0.6028^{* *}$ & $-0.7865^{* *}$ & $-0.8172^{* *}$ \\
Days to Striga emergence vs grain yield & 0.2482 & $0.5319^{*}$ & $0.4759^{*}$ \\
Days to Striga emergence vs plant height & $0.3708^{* *}$ & 0.2172 & 0.3209 \\
AUSNPC vs grain yield & $-0.5402^{* *}$ & $-0.6006^{*}$ & $-0.6118^{* *}$ \\
AUSNPC vs plant height & $-0.5737^{* *}$ & -0.1489 & $-0.4104^{*}$ \\
AUSNPC vs days to flowering & -0.0200 & -0.1565 & -0.1366 \\
Plant height vs grain yield & 0.3448 & 0.2408 & 0.3469 \\
AUSNPC vs Striga flowering & $0.6613^{* *}$ & $0.8234^{* *}$ & $0.8448^{* *}$ \\
AUSNPC vs Striga capsules & $0.8039^{* *}$ & $0.8021^{* *}$ & $0.8550^{* *}$ \\
\hline
\end{tabular}

* Significant.

Highly significant at $P<0.05$.

in different combinations of QTLs $01,02,05_{2}$ and 06 as indicated in Table 7.

Days to Striga emergence was positively correlated with plant height and grain yield in both locations (Table 8). Therefore, as the days to Striga emergence was delayed, plant height and grain yield increased. On the other hand, days to Striga emergence showed strong negative correlation with the number of Striga plants that emerged so that, the earlier the Striga shoots emerged, the higher was the eventual density of the Striga plants observed with a concomitant increase in AUSNPC (Table 8). AUSNPC was negatively correlated with grain yield in both locations. Striga plants flowering

Table 7

Across-location means for agronomic and Striga-related parameters from field trials at two locations, September 2012-February 2013.

\begin{tabular}{|c|c|c|c|c|c|c|c|c|c|c|c|}
\hline No. & Genotype & QTL type & NHRPLR & DF & $\mathrm{PH}$ & GY & DSE & AUS NPC & NSF & NSC & SV \\
\hline 1 & L1P2P13 & 02,06 & 18 & 70.7 & 143.3 & 0.95 & 43.8 & 55.9 & 10 & 7.7 & 5.7 \\
\hline 2 & L2P1P7 & 02,06 & 12 & 69.7 & 130.7 & 1.05 & 48.2 & 50.4 & 9.2 & 7.2 & 5.7 \\
\hline 3 & L2P1P22 & $02,05_{2}, 06$ & 16 & 71.2 & 141.3 & 1.78 & 45 & 46.4 & 8.2 & 7 & 5.2 \\
\hline 4 & L2P2P4 & $02,05_{2}$ & 7 & 71.7 & 158.6 & 0.91 & 41.3 & 54.3 & 9.3 & 7.8 & 5.2 \\
\hline 5 & L2P2P8 & $02,05_{2}$ & 15 & 69.8 & 135.9 & 1.18 & 43 & 49.1 & 8.7 & 6.7 & 5 \\
\hline 6 & L2P2P16 & 2 & 17 & 71.2 & 140.5 & 1.44 & 43 & 57.4 & 9.3 & 7.5 & 6.3 \\
\hline 7 & L2P5P10 & $05_{2}, 06$ & 18 & 70.2 & 129.7 & 1.37 & 46.2 & 53.9 & 9 & 6.8 & 5 \\
\hline 8 & L2P5P11 & $02,05_{2}, 06$ & 16 & 70.5 & 139.1 & 1.71 & 48.2 & 46.1 & 8.3 & 6.3 & 4.2 \\
\hline 9 & L2P5P15 & $02,05_{2}$ & 16 & 70.2 & 133.6 & 1.47 & 47.8 & 51.0 & 8.5 & 6 & 5 \\
\hline 10 & L2P5P22 & $06,05_{2}$ & 19 & 70 & 148.2 & 1.48 & 48.8 & 50.2 & 7.5 & 6 & 5 \\
\hline 11 & L2P5P25 & $02,05_{2}, 06$ & 15 & 70.2 & 134.7 & 1.37 & 47.3 & 49.0 & 7.7 & 6.2 & 4.3 \\
\hline 12 & L2P5P35 & $02,05_{2}, 06$ & 19 & 70.2 & 138.3 & 2.06 & 49.3 & 44.7 & 6.5 & 5 & 4.2 \\
\hline 13 & L2P6P9 & $05_{2}, 06$ & 18 & 72 & 140.3 & 1.8 & 48.7 & 39.9 & 8.5 & 6.5 & 4.8 \\
\hline 14 & L2P6P14 & $02,05_{2}$ & 15 & 68.7 & 153.8 & 1.45 & 45 & 49.2 & 9.8 & 7.2 & 5 \\
\hline 15 & L2P6P29 & $02,05_{2}, 06$ & 16 & 69.7 & 151.8 & 1.89 & 50 & 44.1 & 6.3 & 5 & 4 \\
\hline 16 & L2P6P38 & 02,06 & 15 & 70.3 & 134.8 & 1.4 & 40.8 & 51.6 & 9.2 & 6.8 & 5.3 \\
\hline 17 & L3P1P4 & $02,05_{1}, 05_{2}$ & 14 & 68.5 & 150.5 & 1.04 & 51.3 & 43.8 & 6 & 5 & 4.2 \\
\hline 18 & L2P1P15 & 01,02 & 16 & 70.7 & 151.5 & 1.25 & 45.2 & 51.5 & 6.8 & 5.5 & 5.2 \\
\hline 19 & L3P1P14 & $01,05_{1}, 05_{2}$ & 14 & 71.2 & 152.9 & 1.79 & 53 & 45.1 & 6.3 & 4.7 & 4 \\
\hline 20 & L3P1P23 & $02,05_{2}$ & 18 & 70.2 & 151 & 1.8 & 44.7 & 47.6 & 7.7 & 5.7 & 5.3 \\
\hline 21 & L1P2-A & $01,02,06$ & 12 & 70 & 132 & 1.04 & 49 & 41.4 & 5.7 & 4.3 & 4.5 \\
\hline 22 & L1P5-A & $01,02,06$ & 18 & 69.2 & 152.7 & 2.02 & 50.5 & 41.8 & 5.3 & 5 & 4 \\
\hline 23 & L2P3-B & $01,02,05_{2}, 06$ & 17 & 72 & 156.3 & 2.09 & 53.3 & 36.2 & 5.8 & 4.3 & 3.8 \\
\hline 24 & L2P6-A & $01,05_{2}, 06$ & 18 & 73.3 & 146.7 & 1.95 & 54.2 & 40.1 & 5.5 & 4.5 & 4.2 \\
\hline 25 & L2P7-A & $01,02,05_{2}, 06$ & 15 & 69.7 & 154.7 & 1.91 & 54.3 & 36.5 & 6.2 & 4.5 & 3.8 \\
\hline 26 & L3P3-A & $01,05_{1}, 05_{2}$ & 18 & 71.1 & 146 & 1.93 & 50.7 & 44.7 & 7.8 & 5.7 & 4.3 \\
\hline 27 & L2P6P10 & $01,05_{2}$ & 18 & 71.7 & 152.9 & 1.42 & 44 & 48.3 & 8.3 & 7.2 & 5.2 \\
\hline 28 & L2P6P36 & 6 & 16 & 69.2 & 143.3 & 0.84 & 47.5 & 56.0 & 10.3 & 7.7 & 6 \\
\hline 29 & L2P4P31 & $06,05_{2}$ & 16 & 69.7 & 145.8 & 0.85 & 45 & 50.2 & 7.2 & 5.8 & 4.8 \\
\hline 30 & L2P5P30 & $06,05_{2}$ & 15 & 70.2 & 143.7 & 1.26 & 46.5 & 52.6 & 10.3 & 8.2 & 5.7 \\
\hline 31 & Hugurtay & & & 70.5 & 123.2 & 0.69 & 40.8 & 62.6 & 14 & 11.1 & 7.5 \\
\hline \multirow[t]{5}{*}{32} & N13 & & & 70.2 & 146 & 1.04 & 56.3 & 36.3 & 4 & 3.2 & 3.2 \\
\hline & & F.Pro.G & & 0.003 & $<0.001$ & $<0.001$ & $<0.001$ & $<0.001$ & $<0.001$ & $<0.001$ & $<0.001$ \\
\hline & & F.Pro.G $\times \mathrm{E}$ & & 0.452 ns & 0.036 & $<0.001$ & 0.018 & 0.002 & 0.016 & $0.58 \mathrm{~ns}$ & 0.046 \\
\hline & & G.Mean & & 70.41 & 143.9 & 1.445 & 47.59 & 47.73 & 7.917 & 6.187 & 4.859 \\
\hline & & CV (\%) & & 2.11 & 8.4 & 3.355 & 10.339 & 10.15 & 23.01 & 27.51 & 12.719 \\
\hline
\end{tabular}

Key: NHRPLR = number of homozygous recurrent parent loci recovered from $27 \mathrm{SSR}$ background markers analyzed, QTL $=$ quantitative trait locus, DF $=$ days to $50 \%$ flowering, AUNSPC $=$ area under striga number progress curve, $\mathrm{PH}=$ plant height in $\mathrm{cm}, \mathrm{GY}=$ grain yield in tons $/$ ha, DSE = days to Striga emergence, NSF $=$ Number of Strig $a$ flowered, $\mathrm{NSC}=$ number of Strig $a$ capsule, $S V=$ Strig $a$ vigor, F.pro.G = F probability of genotype, F.pro.G $\times \mathrm{E}=\mathrm{F}$ probability of genotype by environment interaction, G.mean = Grand mean, $\mathrm{CV}=$ coefficient of variation, $\mathrm{ns}=$ non-significant.

Figures in bold indicate the introgression lines that performed best in terms of yield compared to the check varieties under Striga pressure. 


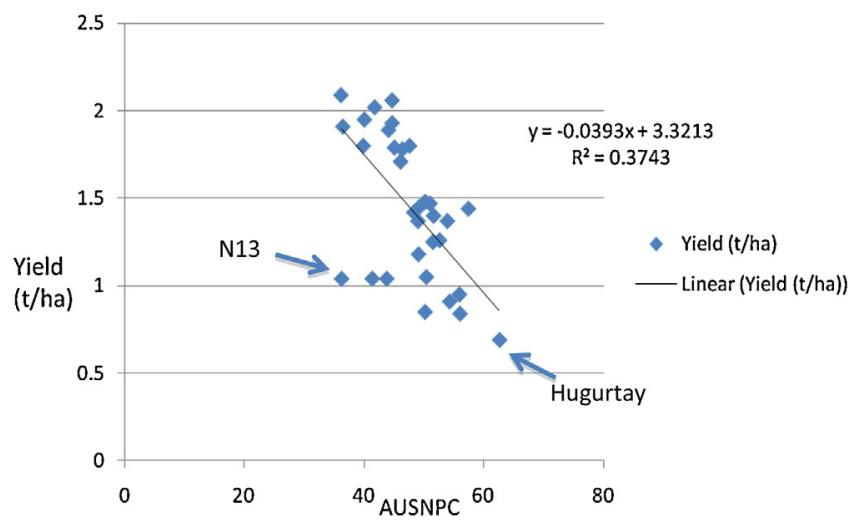

Fig. 2. Relationship between Area Under Striga Number Progress Curve (AUSNPC) and grain yield for combined data from Alupe and Kibos.

and number of Striga seed capsules formed both exhibited strong positive correlation with the number of emerged Striga plants (AUSNPC), confirming that with higher Striga counts, weed productivity was high and more Striga plants flowered and produced seed capsules. Fig. 2 shows the relationship between across-site entry mean AUSNPC and grain yield values for the 32 trial entries. As the number of Striga plants increased, grain yield reduced significantly to below $1 \mathrm{tha}^{-1}$. The equation $y=-0.0393 x+3.3213$ indicates that for every unit increase of AUSNPC, the grain yield was expected to decrease by about $0.0393 \mathrm{tha}^{-1}$. The regression $R^{2}$ indicated that a moderate but significant proportion of variation in mean grain yield was explained by the variation in mean cumulative Striga counts (AUSNPC) across the two sites.

\section{Discussion}

Use of MAS in modern breeding is not new and has been applied for single and multiple traits introgression over the past decade, often in cereals such as barley, rice and wheat (Collard and Mackill, 2008). However, this tool is most successfully exploited by multinational breeding companies and state-of-the art public research institutions. In contrast, the current study was conducted in two geographically distant developing countries, Kenya and Eritrea. All breeding activities were conducted in Eritrea whilst genotyping and final field evaluation was done at ICRISAT-Nairobi since Eritrea has no DNA extraction or genotyping facilities. The appropriate leaf samples were collected and preserved in Eritrea and sent to Kenya for genotyping.

\subsection{SSR genotyping}

DNA extracted from leaf samples that reached ICRISAT-Nairobi in good condition $\left(\mathrm{F}_{1}, \mathrm{BC}_{1} \mathrm{~F}_{1}\right.$ and $\left.\mathrm{BC}_{2} \mathrm{~F}_{2}\right)$ or that were grown from seeds sent to ICRISAT-Nairobi $\left(\mathrm{BC}_{3} \mathrm{~F}_{2}\right)$ was of sufficiently good quality and quantity for the required genotyping for foreground and background screening, since SSR analysis require relatively small amounts of DNA (Powell et al., 1996; Semagn et al., 2006).

During foreground screening of the early generations $\left(\mathrm{F}_{1}, \mathrm{BC}_{1} \mathrm{~F}_{1}\right.$ and $\mathrm{BC}_{2} \mathrm{~F}_{2}$ ) for Striga resistance QTLs introgression, limited polymorphic markers were available for some target QTLs (none for QTL06 and only one each for QTL05 1 and QTL05 2 ). However, during the $\mathrm{BC}_{3} \mathrm{~F}_{2}$ generation, more markers were available from the completed whole genome sequence of sorghum (Paterson et al., 2009) and subsequent identification of numerous genome-wide SSR markers that were reported by Ramu et al. (2010) and Billot et al. (2013). Two polymorphic flanking markers each were used for QTLs $01,05_{1}, 05_{2}$ and 06 , and 3 markers for QTL02; enabling more accurate selection for QTL introgression as the focus was to select plants homozygous for the marker alleles of the donor parent flanking each target locus as described by Hospital (2003).

Results for the $341 \mathrm{BC}_{3} \mathrm{~F}_{2}$ samples genotyped (Table 5) confirmed homozygous (fixed) introgression of resistance alleles at 1 QTL in 141 samples, at 2 QTLs in 56 samples, at 3 QTLs in 17 samples, 4 QTLs in 2 samples and 125 samples with homozygous resistance alleles introgressed at none of the 5 target QTLs. All 5 individual target QTLs were introgressed into at least 15 plants although all introgressions of QTL01 were in combination with at least 1 other QTL. These results allowed the selection of 84 selfed $\mathrm{BC}_{3} \mathrm{~F}_{2}$ plants with different individual QTLs and/or QTL combinations fixed for background screening and field evaluation.

In background (BG) screening, the focus was to identify the $\mathrm{BC}_{3} \mathrm{~F}_{2}$ individuals that had homozygous resistance alleles introgressed at one or more QTL and also achieved the best recovery of the RP genome in the genomic regions not linked to the QTLs (Semagn et al., 2006). BG screening is most effective in the $\mathrm{BC}_{1} \mathrm{~F}_{1}$ generation, when relatively large numbers of plants are genotyped and when large numbers of markers are available that can screen the whole genome at short intervals, which aids identification of linkage drag as well as individuals where such linkage has been overcome that helps to eliminate potentially deleterious genes being introduced from the donor parent (Hospital, 2003). In this study, $\mathrm{BG}$ genotyping of the selected $84 \mathrm{BC}_{3} \mathrm{~F}_{2}$ progeny indicated that 56 individuals exhibited homozygous RP alleles at 15-19 of the 27 SSR loci analyzed, indicating a higher rate of RP recovery compared to the other individuals. This was lower than the expected theoretical RP recovery at $\mathrm{BC}_{3}$ of $93.75 \%$ (Ram and Mishra, 2010), probably due to the simultaneous selection for multiple target QTL introgressions, which will have increased both the amount of linkage drag and the proportion of donor parent allele heterozygosity retained in $\mathrm{BC}_{1} \mathrm{~F}_{1}, \mathrm{BC}_{2} \mathrm{~F}_{2}$ and $\mathrm{BC}_{3} \mathrm{~F}_{2}$ individuals selected for generation advance. Physical examples of high levels of RP recovery in sorghum has not been reported, but Kim et al. (2008) succeeded in $88 \%$ recurrent background recovery at $\mathrm{BC}_{3}$ for soybean. It is this ability to select for the RP recovery outside of the target locus that greatly reduces the number of generations required to develop lines that possess the desired introgression(s) in a given elite background (Hospital, 2003). In this study, 3 backcross generations were sufficient to recover lines that closely resembled Hugurtay RP for morphological traits, instead of the average of 6 generations that are routinely considered necessary, and the selected 84 lines were considered good candidates for field evaluation.

\subsection{Field evaluation of $B C_{3} F_{3}$ lines}

In this study, the results of MAS were verified, after genotyping of the $\mathrm{BC}_{3} \mathrm{~F}_{2}$ generation and selection of the 84 best candidate lines, by field evaluation of the selfed progenies $\left(\mathrm{BC}_{3} \mathrm{~F}_{3}\right)$ to identify the genotypes with improved resistance to Striga infestation combined with agronomic traits of the recurrent parent. Haussmann et al. (2000) suggested that the number of emerged Striga plants, Striga vigor, number of flowering Striga plants, number of Striga plants with seed capsules, days to Striga emergence and yield of the crop under infestation conditions were the most important parameters to consider amongst other agronomic characters of the host.

For all the parameters measured in the field trial, five lines-L2P3-B (QTL01, QTL02, QTL05 2 and QTL06), L2P6-A (QTL02, QTL05 $_{2}$ and QTL06), L2P7-A (QTL01, QTL02, QTL05 2 and QTL06), LP1P5-1 (QTL01, QTL02 and QTL06), and L2P5P35 (QTL02, QTL05 and QTL06)-consistently performed best with regard to the Striga resistance parameters discussed below. All of these five lines had incorporated QTL06 and QTL02, most often in combination with QTL01, QTL05 2 or both of these (in 2 out of these 5 lines) (Table 7). Both lines with 4 QTLs had the same introgression pattern. QTL05 was not present in any of these 5 lines, indicating that QTL05 1 may 
contribute least to the resistance. Gammar and Mohamed (2013) reported that introgression of QTL05 1 and $\mathrm{QTLO}_{2}$ improved field resistance more than the other QTLs in sorghum in Sudan.

Days to first Striga plant emergence was significantly different among the lines evaluated. Emergence of the parasite was slow and delayed by about two weeks in lines L2P3-B (QTL01, QTL02, QTL06 and QTL05 ), L2P6-A (QTL02, QTL06 and QTL05 ), and L2P7A (QTL01, QTL02, QTL06 and QTL05 $)$ compared to the emergence in the susceptible control, Hugurtay (Table 7). Late Striga emergence may be an indication of late attachment of Striga to the sorghum host. Such late attachments could be attributed to the mechanical resistance mechanism of the N13 donor conferred by its Striga resistance QTL alleles. Gebremedhin et al. (2000) also reported delayed emergence of Striga on resistant sorghum compared to a susceptible variety. The genetic differences between the sorghum genotypes have been reported to affect the time of parasite attachment, with resistant varieties showing later attachment and parasite emergence than susceptible cultivars (Ezeaku and Gupta, 2004; Rodenburg et al., 2006). The observed delay in Striga emergence may also be due to reduced or delayed haustorium initiation and attachment. Alternatively, a less competent match between the parasite and the host roots may have resulted in the progeny with newly acquired resistance QTL, reducing the likelihood of a successful parasitic relationship that manifested in the later emergence of successful parasites.

The AUSNPC as described by Haussmann et al. (2000) is considered an appropriate measure for Striga resistance as it incorporates emergence time and numbers of emerged Striga. Omanya et al. (2004) previously noted that the AUSNPC is under strong genetic control and offers a suitable measure of progressive Striga emergence in the field and the authors encouraged its use in screening.

In the current study, the combined ANOVA (Table 7) indicated that Striga infestation over the cropping season, expressed as the AUSNPC, was significantly reduced in the introgressed $\mathrm{BC}_{3} \mathrm{~F}_{4}$ lines compared to the control variety, Hugurtay. Striga counts increased steadily for most lines during crop growth. However, lines L2P3B, L2P7-A, which each had 4 QTLs fixed and lines L1P5-A, L2P6-A, L2P5P35, which each had 3 Striga resistance QTLs fixed, maintained the lowest Striga infestation levels compared to other backcross lines. The RP (and susceptible check) variety, Hugurtay supported the highest number of Striga plants. Haussmann et al. (2000) considered genotypes as resistant when they supported significantly fewer emerged Striga plants than the susceptible check and Rodenburg et al. (2006) reported that the number of emerged Striga plants recorded above ground was significantly correlated with the number of Striga plants attached to the roots in sorghum. The results of this study supported both these trends (Table 8).

Sorghum growth, measured by plant height and grain yield as indicated in the analysis (Table 7) was significantly different among the lines. In a previous report, Ayangowa et al. (2010) noted a reduction of sorghum growth and stunting as dominant symptoms of Striga infestation. Stunted growth is likely to result in reduced grain yield. In this study, the combined ANOVA for the two locations showed the highest mean grain yield of $2.09 \mathrm{tha}^{-1}$ was recorded for line L2P3-B, followed by L2P5P35, L1P5-A and L2P6-A with 2.06, 2.02 and $1.95 \mathrm{tha}^{-1}$ respectively. All of these lines, besides having three to four Striga resistance QTL alleles introgressed and fixed, also had a higher number of the recurrent parent homozygous alleles at the BG marker loci with lines L2P3-B, L1P5-A, L2P6-A that exhibited 17-18 homozygous loci and line L2P5P35 that exhibited 19 out of 27 loci that were screened. These genotypes also closely resembled Hugurtay morphologically, indicating successful genome recovery of the recurrent parent through the successive backcrossing generations. However, Hugurtay yielded poorly at 0.69 tha $^{-1}$, due to the Striga pressure and its susceptible nature. On the other hand, even though N13 supported fewer Striga shoots
(Figure 2) its lower yield could be due to its inherent low yield potential (Ejeta, 2007). Lines with entry numbers 23 (L2P3-B), 12 (L2P5P35), 22 (L1P5-A) and 24 (L2P6-A) were the best performers that also showed good stability across the two locations. In these four lines, the emergence of Striga was also delayed compared to Hugurtay, possibly explaining the higher grain yields obtained.

The lower Striga counts and higher grain yields in the introgressed $\mathrm{BC}_{3} \mathrm{~F}_{2}$-derived introgression lines compared to the RP, Hugurtay, demonstrated that MABC was successful for the introgression of the Striga resistance QTLs from the donor parent, N13. It allowed precise identification of the individuals in each generation that had resistance alleles of the QTLs introgressed and therefore allowed targeted advance of only small numbers of selected individuals in each generation - without the need for phenotypic screening of each generation. These introgressed QTLs in the selected backcross progenies were correlated with delayed emergence, reduced numbers of Striga shoots and improved grain yield. Gammar and Mohamed (2013) also reported reduced Striga emergence and increased sorghum yields after introgressing Striga resistance QTL from N13 into Tabat, a FPSV in Sudan.

The number of Striga plants flowering and those forming capsules are vital to estimate the productivity of the parasite. In this study, the number of Striga plants that flowered and those that formed capsules on the introgressed lines were few compared to the number of emerged Striga shoots in each plot (Table 7). This could reduce the multiplication rate of the Striga and slow down the accumulation of seeds in the soil. Rodenburg et al. (2006) also identified host resistance as an important determinant of Striga reproduction. However, the very large seed production capacity of Striga means that there may still be capacity for the Striga population to rapidly adapt to the resistance QTLs being deployed as even the reduced number of flowering plants may be enough to maintain soil seed banks at levels sufficient for significant levels of infestation of a resistant host unless resistance deployment is accompanied by removal of emerged Striga plants prior to seed dispersal, or other weed management measures (Rodenburg et al., 2006).

Visual evaluation of Striga vigor at maturity varied from approximately 4 (Striga height $21-30 \mathrm{~cm}$ and number of branches on Striga plant $\leq 5$ ) to 8 (Striga height $>40 \mathrm{~cm}$ and number of branches on Striga plant $\leq 10$ ) (Table 7). In the majority of backcross lines, Striga plant vigor was on average, less than $40 \%$ of that of the recurrent parent Hugurtay. Rodenburg et al. (2006) suggested that Striga plant vigor influences mortality and seed production capacity. In this study Striga vigor and capsule number were positively correlated (Table 8).

\section{Conclusions}

The results of this study clearly demonstrated the potential of using exotic donor germplasm to improve adapted local material in combination with marker-assisted selection and backcrossing. Up to four Striga resistance QTLs were fixed in genotypes L2P5P35, L2P3-B, L2P6-A, L1P5-A and L2P7-A, all of which had also recovered relatively high proportion of the recurrent parent, Hugurtay, genome at the background SSR loci analyzed. The identification of these five genotypes is expected to have a positive impact on improving sorghum productivity in the Striga prone areas of Eritrea, provided that the introgressed resistance QTLs are indeed effective against $S$. hermonthica populations in those regions.

QTL pyramiding can be done in the future by crossing the introgressed genotypes L2P3-B and L3P3A to incorporate the fifth Striga resistance QTL05 1 to further improve the results obtained from this study. Genotype L2P3-B had introgressed four QTLs namely QTL01, QTL02, QTL06 and QTL052 and genotype L3P3-A three QTLs namely QTL01, QTL05 1 and QTLO5 $_{2}$. These genotypes also 
performed among the best agronomically. Furthermore, the best genotypes in this study will in future be invaluable to plant breeders in the Eastern and Central Africa region in their sorghum improvement programs.

\section{Acknowledgments}

This work has been undertaken as part of the CGIAR Research Program on Dryland Cereals and the ABCIC Striga Resistance Evaluation Project with funding from BMZ and ASARECA.

\section{Appendix A. Supplementary data}

Supplementary data associated with this article can be found, in the online version, at http://dx.doi.org/10.1016/j.fcr.2014.12.008.

\section{References}

Ayangowa, G.C., Stomph, T.J., Hoevers, R., Ngoumou, T.N., Kuyper, T.W., 2010. Striga infestation in northern Cameroon: magnitude, dynamics and implications for management. Njas-Wageningen J. Life Sci. 57, 159-165.

Billot, C., Ramu, P., Bouchet, S., Chantereau, J., Deu, M., Gardes, L., Noyer, J.-L., Rami, J.F., Rivallan, R., Li, Y., Lu, P., Wang, T., Folkertsma, R.T., Arnaud, E., Upadhyaya, H.D. Glaszmann, J.-C., Hash, C.T., 2013. Massive sorghum collection genotyped with SSR markers to enhance use of global genetic resources. PLOS ONE 8, e59714, http://dx.doi.org/10.1371/journal.pone.0059714.

Collard, B.C.Y., Mackill, D.J., 2008. Marker-assisted selection: an approach for precision plant breeding in the twenty-first century. Philos. Trans. R. Soc. B 363. 557-572, http://dx.doi.org/10.1098/rstb.2007.2170.

Ejeta, G., 2007. Breeding for Striga resistance in sorghum: exploitation of an intricate host-parasite biology. Crop Sci. 47, 216-227.

Ejeta, G., Gressel, J., 2007. Integrating New Technologies for Striga Control: Towards Ending the Witch-hunt. World Scientific, River Edge, NJ, USA, pp. 27-29.

Ezeaku, I.E., Gupta, S.C., 2004. Development of sorghum populations for resistance to Striga hermonthica in the Nigerian Sudan Savanna. Afr. J. Biotechnol. 3, 324-329.

FAOSTAT, 2011, Retrieved from: http://faostat3.fao.org/faostat-gateway/go/to/ download $/ \mathrm{Q} / * / \mathrm{E}$ (accessed 11.08.13).

Folkertsma, R.T., Rattunde, H.F.W., Chandra, S., Raju, G.S., Hash, C.T., 2005. The pattern of genetic diversity of Guinea-race Sorghum bicolor (L.) Moench landraces as revealed with SSR markers. Theor. Appl. Genet. 111, 399-409.

Frisch, M., Bohn, M., Melchinger, A.E., 1999. Comparison of selection strategies for marker-assisted backcrossing of a gene. Crop Sci. 39, 1295-1301.

Gammar, Y.A., Mohamed, A.H., 2013. Introgression of Striga resistance genes into a Sudanese sorghum cultivar, Tabat, using marker-assisted selection (MAS). Greener J. Agric. Sci. 3, 550-556.

Gebremedhin, W., Goudriaan, J., Naber, H., 2000. Morphological, phenological and water-use dynamics of sorghum varieties (Sorghum bicolor) under Striga hermonthica infestation. Crop Prot. 19, 61-68.

Haussmann, B.I.G., Hess, D.E., Reddy, B.V.S., Welz, H.G., Geiger, H.H., 2000. Analysis of resistance to Striga hermonthica in diallel crosses of sorghum. Euphytica 116 , $33-40$.

Haussmann, B.I.G., Hess, D.E., Omanya, G.O., Folkertsma, R.T., Reddy, B.V.S., Kayentao, M., Geiger, H.H., 2004. Genomic regions influencing resistance to the parasitic weed Striga hermonthica in two recombinant inbred populations of sorghum. Theor. Appl. Genet. 109, 1005-1019.
Hayden, M., Nguyen, T., Waterman, A., Chalmers, K., 2008. Multiplex-ready PCR: a new method for multiplexed SSR and SNP genotyping. BMC Genomics 9, 80.

Hospital, F., 2003. Marker-assisted breeding. In: Newbury, H.J. (Ed.), Plant Molecular Breeding. Blackwell Publishing and CRC Press, Oxford and Boca Raton, pp. 30-59.

Hospital, F., Charcosset, A., 1997. Marker-assisted introgression of quantitative trait loci. Genetics 147, 1469-1485

Jamil, M., Kanampiu, F.K., Karaya, H., Charnikhova, T., Bouwmeester, H.J., 2012. Striga hermonthica parasitism in response to $\mathrm{N}$ and P fertilisers. Field Crops Res. 134 $1-10$.

Kim, J.S., Childs, K.L., Islam-Faridi, M.N., Menz, M.A., Klein, R.R., Klein, P.E., Price, H.J., Mullet, J.E., Stelly, D.M., 2004. Integrated karyotyping of sorghum by in situ hybridization of landed BACs. Genome 45, 402-412.

Kim, K.H., Kim, M.Y., Van, K., Moon, J.K., Kim, D.H., Lee, S., 2008. Marker-assisted foreground and background selection of near isogenic lines for bacterial leaf pustule resistant gene in soybean. J. Crop Sci. Biotechnol. 11, 263-268.

Lammerts van Bueren, E.T., Backes, G., de Vriend, H., Ostergard, H., 2010. The role of molecular markers and marker assisted selection in breeding for organic agriculture. Euphytica 175, 51-64

Mace, E.S., Buhariwalla, H.K., Crouch, J.H., 2003. A high-throughput DNA extraction protocol for tropical molecular breeding programs. Plant Mol. Biol. Rep. 21, 459-460.

Ministry of Agriculture, Eritrea, 2010. Planning and Statistics Annual Report.

Mohamed, A., Ali, R., Elhassan, O., Suliman, E., Mugoya, C., Masiga, C.W., Hash, C.T., 2014. First products of DNA marker-assisted selection in sorghum released for cultivation by farmers in sub-Saharan Africa. J. Plant Sci. Mol. Breed. 3, 2050-2389 http://www.hoajonline.com/journals/pdf/2050-2389-2-4

Omanya, G.O., Haussmann, B.I.G. Hess, D.E., Reddy, B.V.S., Kayentao, M., Welz, H.G., Geiger, H.H., 2004. Utility of indirect and direct selection traits for improving Striga resistance in two sorghum recombinant inbred populations. Field Crops Res. 89, 237-252

Paterson, A.H., Bowers, J.E., Bruggmann, R. Dubchak, I., Grimwood, J., Gundlach, $\mathrm{H}_{\text {, }}$ Haberer, G., Hellsten, U., Mitros, T., Poliakov, A., Schmutz, J., Spannagl, M., Tang, H., Wang, X., Wicker, T., Bharti, A.K., Chapman, J., Feltus, F.A., Gowik, U., Grigoriev, U.V., Lyons, E., Maher, C.A., Martis, M., Narechania, A., Otillar, R.P., Penning, B.W., Salamov, A.A., Wang, Y., Zhang, L., Carpita, N.C., Freeling, M., Gingle, A.R., Hash, C.T., Keller, B., Klein, P., Kresovich, S., McCann, M.C., Ming, R., Peterson, D.G., Mehboob-ur-Rahman, Ware, D., Westhoff, P., Mayer, K.F.X., Messing, J., Rokhsa, D.S., 2009. The Sorghum bicolor genome and the diversification of grass. Nature 457, 551-556, http://dx.doi.org/10.1038/nature07723.

Powell, W., Machery, G.C., Pravan, J., 1996. Polymorphism revealed by simple sequence repeats. Trends Genet. 1, 76-83.

Ram, S., Mishra, B., 2010. Cereals: Processing and Nutritional Qualities. New India Publishing Agency, Delhi, India, pp. 184.

Ramu, P., Deshpande, S.P., Senthilvel, S., Jayashree, B., Billot, C., Deu, M., Ananda Reddy, L., Hash, C.T., 2010. In silico mapping of important genes and markers available in the public domain for efficient sorghum breeding. Mol. Breed. 26, 409-418, http://dx.doi.org/10.1007/s11032-009-9365-9.

Rodenburg, J., Bastiaansa, L.E., Weltzienb, D., Hessc, E., 2005. How can field selection for Striga resistance and tolerance in sorghum be improved? Field Crops Res. 93, 34-50.

Rodenburg, J., Bastiaans, L., Kropff, M.J., van Ast, A., 2006. Effects of host plant genotype and seed bank density on Striga reproduction. Weed Res. 46, 251-263.

Schuelke, M., 2000. An economic method for the fluorescent labelling of PCR fragments. Nat. Biotechnol. 18, 233-234.

Semagn, K., Bjornstad, A., Ndijiondjop, M.N., 2006. An overview of molecular marker methods for plants. Afr. J. Biotechnol. 5, 2540-2568.

Tesfamichael, A., Nyende, A.B., Githiri, S.M., Kasili, R.W., Woldeamlak, A., 2013. Documentation of sorghum (Sorghum bicolor L. Moench) landraces: production, utilization and challenges in Eritrea. J. Agric. Biol. Sci. 8, 498-508. 